\title{
Pengaruh Kinerja Keuangan Daerah Terhadap Belanja Modal Pada Kabupaten/Kota Se-Bakorwil Madiun
}

\author{
Nurharibnu Wibisono $^{1)}$, Mintarti Indartini ${ }^{2)}$, Endang Edi Rahayu ${ }^{3)}$ \\ 1)Program Studi Akuntansi, Universitas Merdeka Madiun, Jalan Serayu 79, Kota Madiun, 63113, \\ Email: nurharibnu@unmer-madiun.ac.id \\ 2)Program Studi Manajemen, Universitas Merdeka Madiun, Jalan Serayu 79, Kota Madiun, 63113 \\ Email: mintarti@unmer-madiun.ac.id \\ ${ }^{3)}$ Program Studi Manajemen, Universitas Merdeka Madiun, Jalan Serayu 79, Kota Madiun, 63113, \\ Email: endangedirahayu@unmer-madiun.ac.id
}

\begin{abstract}
The goals of its research was to decide the impact of Regional Financial Independence (KKD), the effect of Fiscal Decentralization (DF), the effect of PAD Effectiveness, also Regional Financial Efficiency (EKD) to Capital Expenditures (BM) partially and generally. The study data derive the Regency and City APBD in the Madiun Bakorwil 2014-2019, namely Madiun Regency, Magetan Regency, Ngawi Regency, Ponorogo Regency, Pacitan Regency, also Madiun City. The method of data analysis used multiple regression by SPSS V-20. The output indicated that KKD had an effect on $B M$, DF had an effect on BM, PAD Effectiveness had no effect on BM, EKD had an effect on Capital Expenditures. The adjusted $R^{2}$ value is 0.408 , meaning that the influence of the KKD, DF, PAD Efficiency and KD Effectiveness variables on Capital Expenditures is $41 \%$ while the residual $59 \%$ is affected by outside of other variables not checked in this research.
\end{abstract}

Keywords - Financial Performance, Financial Independence, Fiscal Decentralization, Effectiveness, Efficiency, Capital Expenditure

\section{PENDAHULUAN}

Buah dari reformasi adalah diperlukannya otonomi daerah dengan tujuan untuk mempercepat distribusi kue pembangunan sehingga keadilan dan kemakmuran lebih cepat diperoleh. Pemerintah daerah diharapkan mampu berkompetisi menggali potensi dan menciptakan kemakmuran daerahnya. Selanjutnya potensi daearh yang tergali harus didistribusikan kepada belanja-belanja yang dibutuhkan oleh masyarakat dan operasional Pemerintah Daerah. Kinerja Pemerintah Daerah harus dimandirikan dan diukur dengan metode tertentu, seperti analisis rasio-rasio keuangan.

Perbandingan keuangan dalam Laporan Realisasi Anggaran (LRA) dan laporan keuangan Pemda lainnya sangat penting untuk mengukur keberhasilan Pemda. Kinerja keuangan suatu Pemda bisa dinilai dengan analisis rasio keuangan di antaranya adalah Rasio Kemandirian Keuangan Daerah (KKD), Rasio Desentralisasi Fiskal (DF), Rasio Efektivitas PAD, dan Rasio Efisiensi Keuangan Daerah (EKD). Di samping itu juga ada Rasio Keserasian Belanja serta Rasio Pertumbuhan.

Transfer fiskal dari Pemerintah Pusat dimaksudkan untuk mengurangi kesenjangan antara provinsi dan kabupaten, serta mewujudkan perbaikan layanan di daerah. Pemerintah Pusat membangun pondasi guna memperkokoh "kontrak sosial fiskal" antara Pemerintah Daerah denga rakyat, namun butuh mendorong pelaksanaan kemandirian Pemerintah Daerah untuj menggali PAD serta meminta akuntabilitas belanja daerah secara efektif dan efisien (Kajian Belanja Publik Indonesia, 2020).

Transfer keuangan perimbangan dari pusat yaitu DAU, DAK serta DBH yang berasal dari pajak dan sumber daya alam (Undang-Undang Republik Indonesia No. 23/2014 Tentang Pemerintahan Daerah). Pemda juga mempunyai sumber dana mandiri yaitu PAD, Pembiayaan dan lain sebagainya. Pemda hendaknya mampu mengeluarkan dana itu secara efisien dan efektif dan mempertanggungjawabkannya untuk masyarakat.

Belanja Modal yaitu belanja anggaran guna mendapatkan harta tetap serta harta yang lain yang bermanfaat melewati satu tahun atau satu periode akuntansi (Peraturan Pemerintah Republik Indonesia No. 71/2010 Tentang Standar Akuntansi Pemerintahan). Contoh belanja modal yaitu belanja mendapatkan tanah, bangunan dan gedung, peralatan, serta aset tak berwujud. Belanja Modal mengilustrasikan usaha Pemda untuk membangun wilayahnya. Demi mempercepat pembangunan serta peningkatan ekonomi daerah, Pemda perlu mengalokasikan Belanja Modal yang signifikan pada pos Belanja Daerah.

Pembangunan fasilitas umum dan infrastruktur bisa mendorong kualitas public service serta bisa menarik investor untuk menanamkan modalnya. Aktivitas ini diharapkan mampu meningkatkan pendapatan per-kapita daerah serta meningkatkan pertumbuhan ekonomi.

Rata-rata Pemda kabupaten/kota di Jawa Barat mempunyai rasio BM yang rendah. Selanjutnya, rasio ruang fiskal sedang, ketergantungan tinggi pada pemerintah pusat serta pengelolaan belanja yang kurang efisien. Namun efektivitas PAD tinggi (Novita \& Nurhasanah, 2020). 
Website : http://ekomaks.unmermadiun.ac.id

BM tidak dipengaruhi oleh desentralisasi fiskal, BM tidak dipengaruhi oleh rasio efektivitas, dan BM dipengaruhi oleh rasio efisiensi (Andriyani, Mukhzarudfa, \& Diah PA, 2020). KKD tidak berpengaruh positif signifikan pada BM, efektivitas PAD tidak berpengaruh positif signifikan kepada BM, serta Efisiensi KD berpengaruh positif signifikan kepada BM (Arif \& Arza, 2018).

Rasio DDF, KKD, derajat pembiayaan SiLPA, serta tingkat sumbangan BUMD berpengaruh positif signifikan pada BM. KKD dengan proksi rasio efektivitas PAD, dan efisiensi KD berpengaruh negatif tidak signifikan pada BM (Indiyanti \& Rahyuda, 2018)

Rasio ketergantungan daerah berpengaruh negatif signifikan pada BM, rasio efektivitas PAD berpengaruh positif tidak signifikan terhadap BM, rasio derajat pembiayaan SiLPA berpengaruh negatif signifikan terhadap BM, rasio ruang fiskal berpengaruh positif signifikan terhadap BM. Rasio efisiensi berpengaruh negatif signifikan terhadap BM, serta rasio sumbangan BUMD berpengaruh positif tidak signifikan terhadap BM (Martini \& Dwirandra, 2015).

Hal ini mendorong peneliti untuk mengkaji pengaruh KKD pada alokasi BM di kabupaten/kota di Bakorwil Madiun.

\section{METODE PENELITIAN}

Data riset adalah LKPD berupa APBD Realisasi kota/kab. di Bakorwil Madiun periode 2014-2019, yaitu Kab. Madiun, Kab. Magetan, Kab. Ngawi, Kab. Ponorogo, Kab. Pacitan, serta Kota Madiun. Sumber data sekunder dari website DJPK RI. Purposive sampling ditujukan untuk memilih data sampel melalui pertimbangan tertentu (Sugiyono, 2015).

Variabel riset yaitu:

1. Kemandirian Keuangan Daerah (X1) yaitu ketidaktergantungan suatu daerah dengan rumus perhitungan rasio realisasi PAD dengan Transfer Pusat/Provinsi serta Pinjaman.

2. Desentralisasi Fiskal (X2) ialah tingkat kemampuan fiskal daerah dihitung melalui rasio realisasi PAD dengan realisasi total pendapatan daerah.

3. Efektivitas PAD (X3) adalah kemmpuan daerah untuk mewujudkan PAD berdasarkan potensi riil, dihitung dengan rasio Penerimaan PAD realisasi dengan anggaran PAD.

4. Efisiensi Keuangan Daerah (X4) merupakan rasio total Belanja Daerah realisasi dengan total Pendapatan realisasi.

5. Belanja Modal (Y) adalah rasio Belanja Modal dengan Total Belanja.

Langkah-langkah penelitian yang digunakan adalah :

1. Deskriptif statistik

2. Pengujian asumsi klasik

3. Analisis regresi berganda

Koefisien regresi didapatkan melalui prediksi angka variabel terikat melalui suatu persamaan. Maksud perolehan koefisien regresi untuk meminimalkan penyimpangan nilai aktual dengan nilai estimasi variabel dependen berdasarkan data. (Tabachnick dalam Ghozali, 2011).

Persamaan regresi: $B M=a+b_{1} X_{1}+b_{2} X_{2}+b_{3} X_{3}+b_{4} X_{4}+b_{5} X_{5}+e$

$\begin{array}{ll}\mathrm{Y} & \text { : Rasio Belanja Modal (BM) } \\ \mathrm{X}_{1} & \text { : Rasio Kemandirian Keuangan Daerah (KKD) } \\ \mathrm{X}_{2} & \text { : Rasio Desentralisasi Fiskal (DF) } \\ \mathrm{X}_{3} & \text { : Rasio Efektivitas PAD (EPAD) } \\ \mathrm{X}_{4} & \text { : Rasio Efisiensi Keuangan Daerah (EKD) }\end{array}$

4. Determinasi

5. Uji t

6. Uji F

\section{III.HASIL DAN PEMBAHASAN}

\section{A. Hasil Riset}

Jumlah pengamatan dalam penelitian ini 6 Pemerintah Daerah di Bakorwil Madiun periode tahun $2014-2019$ yaitu $\mathrm{n}=$ 36 Laporan Realisasi Anggaran, semuanya yang memenuhi kriteria pengujian SPSS.

1. Descriptive Statistics

Tabel 1. Descriptive Statistics

\begin{tabular}{|l|r|r|r|r|r|}
\hline & N & Minimum & Maksimum & Rata-rata & \multicolumn{1}{c|}{ Std. Deviasi } \\
\hline X1 & 36 & 8.00 & 32.00 & 14.4722 & 5.68952 \\
X2 & 36 & 8.00 & 24.00 & 12.4722 & 3.94596 \\
X3 & 36 & 85.00 & 168.00 & 129.4444 & 16.95278 \\
X4 & 36 & 89.00 & 113.00 & 100.0556 & 5.88433 \\
Y & 36 & 9.00 & 33.00 & 18.1389 & 4.69743 \\
Valid N & 36 & & & & \\
\hline
\end{tabular}

Sumber: Hasil ouput SPSS Versi 20 
Penjelasan statistik deskriptif (Tabel 1) adalah:

a. Rasio Kemandirian Keuangan Daerah

KKD memiliki angka minimum sebanyak 8.00 ialah Kab. Ngawi periode 2018. Angka maximum-nya sebesar 32.00, yaitu Kota Madiun periode 2017. Angka rata-ratanya sebanyak 14.47. Beda angka sampel terhadap ratarata Rasio Kemandirian Keuangan Daerah (X1) sebesar 5.68952.

b. Rasio Desentralisasi Fiskal

Selama tahun 2013 - 2019, variabel Rasio Desentralisasi Fiskal (DF), (X2) memiliki angka minimum sebanyak 8.00 ialah Kab. Ngawi periode 2018. Angka maximum-nya sebesar 24.00, yaitu Kota Madiun periode 2017. Angka mean sebanyak 12.47. Beda angka sampel terhadap rata-rata Rasio Desentralisasi Fiskal (DF), (X2) sebesar 3.94596.

c. Rasio Efektifitas PAD

Selama tahun 2013 - 2019, variabel Rasio Efektifitas PAD (X3) memiliki angka minimum sebanyak 85.00 adalah Kab. Ngawi periode 2018. Angka maximum-nya sebesar 168.00 adalah Kab. Ngawi periode 2014. Mean senayak 129.44. Beda sampel terhadap rata-rata (standar deviasi) dari Rasio Efektifitas PAD (X3) sebesar 16.95278.

d. Rasio Efisiensi Keuangan Daerah

Selama tahun 2013 - 2019, variabel Rasio Efisiensi Keuangan Daerah (X4) memiliki angka minimum sebanyak 89.00 ialah Kab. Pacitan periode 2018. Angka maximum-nya sebanyak 113.00 ialah Kab. Pacitan periode 2017. Angka mean sebanyak 100.05. Beda sampel terhadap rata-rata dari Rasio Efisiensi Keuangan Daerah (X4) sebesar 5.88433 .

e. Rasio Belanja Modal

Selama tahun 2013 - 2019, variabel Rasio Belanja Modal (Y) memiliki nilai minimum sebesar 9.00 ialah Kab. Madiun periode 2019. Angka maximum-nya sebanyak 33.00, yaitu Kab. Madiun periode 2016. Nilai rerata 18.1389. Std deviasi dari Rasio Belanja Modal (Y) sebesar 4.69743.

2. Asumsi Klasik

\section{a. Normalitas}

Pengujian kenormalan bermaksud guna mengetahui suatu model regresi dan variabel pengganggu mempunyai normal distribution (Ghozali, 2011).

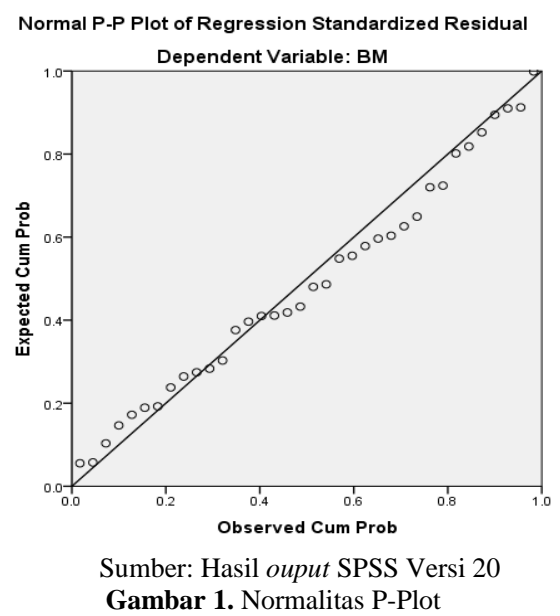

Pada grafik normalitas dapat disimpulkan, residual regression berpola normal karena titik-titik menyebar pada area garis diagonal serta mengikuti garis diagonal. Artinya model regresi layak digunakan.

Uji Kolmogorov-Smirnov (Tabel 2) bernilai 0,550, taraf signifikan 0,923>5\%. Artinya data penelitian berdistribusi normal.

Tabel 2. Pengujian Normalitas K-S One-Sample

\begin{tabular}{|c|c|c|}
\hline & & Unstandardized Res. \\
\hline $\mathrm{N}$ & & 36 \\
\hline \multirow{3}{*}{ Normal Parameter ${ }^{a, b}$} & Rata-rata & $0 \mathrm{E}-7$ \\
\hline & Std. Deviasi & 3.40288059 \\
\hline & Absolut & .092 \\
\hline \multirow[t]{2}{*}{ Most Extreme Difference } & Positiv & .092 \\
\hline & Negativ & -.049 \\
\hline $\mathrm{K}-\mathrm{S} \mathrm{Z}$ & & .550 \\
\hline Asymp. Sig. (2-tailed) & & .923 \\
\hline
\end{tabular}

a. Test distribution is Normal.

Sumber: Hasil ouput SPSS Versi 20 
b. Heteroskedastisitas

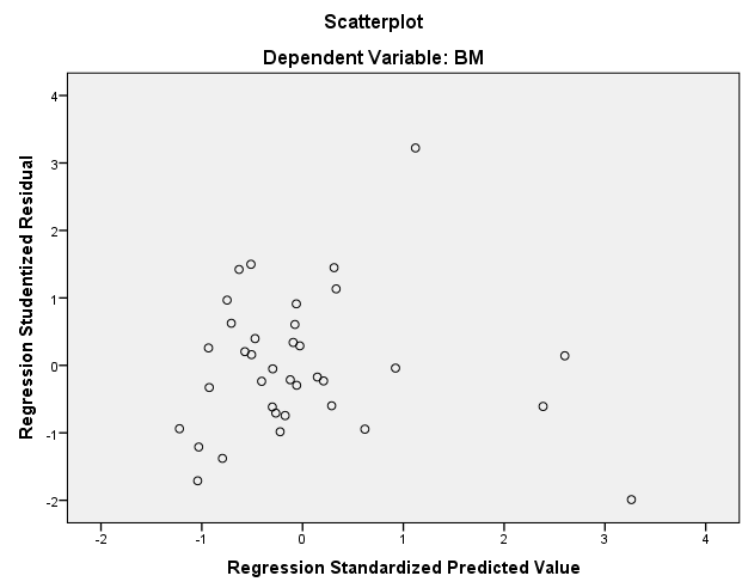

Sumber: Ouput SPSS Versi 20

Gambar 2. Uji Heterokedastisitas

Gambar 2 memperlihatkan sebaran noktah di atas sumbu 0 dan di bawah sumbu 0 pada sumbu y dan bukan berpola. Artinya, model regresi terhindar dari heteroskedastisitas.

c. Autokorelasi

Tabel 3 menunjukkan $\mathrm{n}=36$ dan $\mathrm{k}=4$. Nilai $\mathrm{dU}=1.7245, \mathrm{dL}=1.2358$, serta $4-\mathrm{dL}=2.7642$. Rumus : $\mathrm{dU}<\mathrm{DW}<4-\mathrm{dL}=1.7245<1.886<2.7642$. Artinya tanpa autokorelasi.

Tabel 3. Autokorelasi D-W

\begin{tabular}{|c|c|}
\hline $\begin{array}{c}\text { Std. Error of the } \\
\text { Estimate }\end{array}$ & Durbin-Watson \\
\hline 3.61576 & 1.886 \\
\hline
\end{tabular}

Sumber: Ouput SPSS Versi 20

3. Pembahasan Regresi

Tabel 4. Analisis Regresi

\begin{tabular}{|l|r|r|r|r|r|}
\hline \multirow{2}{*}{ Model } & \multicolumn{2}{|c|}{ Unstandardized Coefficients } & \multicolumn{1}{|c|}{$\begin{array}{c}\text { Standardized } \\
\text { Coefficients }\end{array}$} & \multirow{2}{*}{ Sig. } \\
\cline { 2 - 4 } & \multicolumn{1}{|c|}{$\mathrm{B}$} & Std. Error & \multicolumn{1}{c|}{ Beta } & & \\
\hline (Konstanta) & -10.757 & 13.592 & & -.791 & .435 \\
X1 & 2.899 & 1.137 & 3.511 & 2.550 & .016 \\
X2 & -3.557 & 1.649 & -2.988 & -2.158 & .039 \\
X3 & .050 & .040 & .179 & 1.252 & .220 \\
X4 & .249 & .116 & .311 & 2.137 & .041 \\
\hline
\end{tabular}

Sumber: Hasil ouput SPSS Versi 20

Berdasarkan Tabel 4 dirumuskan regresi:

$\mathrm{BM}=-10.757+2.899 \mathrm{X}_{1}-3.557 \mathrm{X}_{2}+0.050 \mathrm{X}_{3}+0.249 \mathrm{X}_{4}+\mathrm{e}$

Konstanta -10.757 menunjukkan bahwa jika variabel KKD, DF, EPAD dan EKD pada BM bernilai 0, maka BM sama dengan -10.757 .

Koefisien KKD berangka 2.899, berarti apabila KKD naik 1 satuan, artinya Belanja Modal akan meningkat sebanyak 2.899 dengan anggapan variabel bebas lainnya stagnan.

Koefisien DF bernilai - 3.557 berarti apabila DF naik 1 satuan, artinya Belanja Modal akan turun senilai -3.557 dengan anggapan variabel bebas lainnya stagnan.

Koefisien Efektifitas PAD senilai 0.050 berarti apabila EPAD naik 1 satuan, menyebabkan BM meningkat senilai 0.05 , anggapannya variabel bebas yang lain stagnan.

Koefisien Efisiensi KD sebanyak 0.249 berarti apabila Efisiensi KD naik 1 satuan, maka Belanja Modal naik juga sebesar 0.249 , asumsinya independent variabel lain stagnan.

4. Determinasi $\left(\mathrm{R}^{2}\right)$ 
Website : http://ekomaks.unmermadiun.ac.id

Tabel 5. Determinasi

\begin{tabular}{|l|r|r|r|c|}
\hline Model & $\mathrm{R}$ & $\mathrm{R}^{2}$ & Adj. $\mathrm{R}^{2}$ & $\begin{array}{c}\text { Std. Error of the } \\
\text { Estimasi }\end{array}$ \\
\hline 1 & $.689^{\mathrm{a}}$ & .475 & .408 & 3.61576 \\
\hline
\end{tabular}

Koefisien korelasi (R) sebesar 0.689 dan $\mathrm{R}^{2}$ adalah 0.475 . Nilai Adjusted $R^{2}$ adalah 0.408 artinya bahwa pengaruh variabel KKD, DF, Efisiensi PAD dan Efektifitas KD terhadap BM senilai 41\%, saldonya 59\% disebabkani variabel di luar penelitian ini.

5. Uji t

Terlihat pada Tabel 5, signifikansi uji t KKD bernilai $0.016<0.05$, artinya KKD (X1) berpengaruh pada BM. DF bernilai $0.039<0.05$, artinya DF (X2) berpengaruh pada BM. Efektifitas PAD bernilai $0.220>0.05$, EPAD (X3) tidak berpengaruh pada BM. Efisiensi KD bernilai $0.041<0.05$, artinya Efisiensi $\mathrm{KD}\left(\mathrm{X}_{4}\right)$ berpengaruh terhadap Belanja Modal.

6. Uji F

Tabel 6. Uji Simultan
\begin{tabular}{|l|r|r|r|r|c|}
\hline Model & Sum of Squares & \multicolumn{1}{|c|}{ df } & \multicolumn{1}{|c|}{ Mean $^{2}$} & F & Sig. \\
\hline Regresi & 367.020 & 4 & 91.755 & 7.018 & $.000^{\mathrm{b}}$ \\
1 Residu & 405.286 & 31 & 13.074 & & \\
Total & 772.306 & 35 & & & \\
\hline
\end{tabular}
a. Dependen Variabel: Y
b. Prediktor: (Konstan), X4, X1, X3, X2
Sumber: Hasil ouput SPSS V.20

Tabel 6 diketahui nilai signifikan $0,000<0,05$, Artinya KKD, DF, Efektifitas PAD, dan Efisiensi KD secara simultan berpengaruh pada BM.

\section{B. PEMBAHASAN PENELITIAN}

1. KKD pada BM

Hasil pengujian SPSS menyimpulkan BM dipengaruhi KKD. Kemampuan Pemda dalam mendanai kegiatan pembangunan serta public services dan juga operasional pemerintahan menunjukkan suatu kemandirian daerah. Hal ini merupakan akuntabilitas pada rakyat sebagai pembayar retribusi serta pajak daerah. Secara umum, kondisi Pemda belum menunjukkan kemajuan yang berarti dalam mencapai kemandirian daerah. Belanja modal harus diwujudkan Pemda untuk memperoleh harta tetap yang berumur lewat dari satu periode/tahun, di antaranya pengadaan tanah, bangunan dan gedung, peralatan, dan lain-lain.

Hasil ini sejalan dengan kesimpulan penelitian Indiyanti \& Rahyuda (2018) yang menyimpulkan KKD berpengaruh positif signifikan pada alokasi BM. Tetapi bertolak belakang dengan kesimpulan studi dari Arif \& Arza (2018), berkesimpulan KKD tidak berpengaruh positif signifikan pada BM.

2. DF pada BM

Pengujian regresi menyimpulkan DF (X2) berpengaruh pada (Y) sehingga H2 diterima. Kemampuan Pemda dalam menghimpun potensi PAD yang berasal dari retribusi dan pajak daerah serta sumber pendapatan lainnya merupakan desentralisasi fiskal. Kemandirian finansial daerah harus terus dipupuk dalam rangkan otonomi daerah agar tidak tergantung pada transfer dana perimbangan saja. Selanjutnya kemandirian fiskal ini diharapkan teralokasi dengan baik pada belanja modal.

Amanah pasal 33 UUD 1945, menghendaki supaya kekayaan alam yang menguasai hajat hidup rakyat dikuasai oleh negara demi kesejahteraan rakyat. Dampak penguasaan ini pemerintah pusat mendapatkan PPN, sedangkan Pemda dirasahan minim dalam pembagian hasil. Di sisi lain Pemda hanya mengambil sumber penghasilan yang kurang menguntungkan, seperti pajak hotel dan restoran, pajak iklan, dan lain-lain. Hal tersebut mengakibatkan kemandirian fiskal daerah menjadi kurang.

Hasil ini sejalan dengan kesimpulan studi, rasio BM dipengaruhi secara positif signifikan oleh alokasi BM (Indiyanti \& Rahyuda, 2018). Rasio alokasi BM dipengaruhi positif signifikan oleh ruang fiskal (Martini \& Dwirandra, 2015). Namun bertolak belakang dengan rasio DF tidak berpengaruh pada BM (Andriyani, Mukhzarudfa, \& Diah PA, 2020).

3. Pengaruh Efektivitas PAD pada BM

Pengujian regresi menyimpulkan, rasio Efektifitas PAD (X3) tidak berpengaruh pada BM (Y), artinya H3 ditolak. Di sini terlihat bahwa efektifitas PAD pemerintah daerah di Bakorwil Madiun belum baik. Rasio efektivitas PAD menunjukkan kemampuan Pemda dalam menghasilkan PAD. Kesimpulan studi ini menunjukkan sebaliknya. Pemda 
Website : http://ekomaks.unmermadiun.ac.id

masih lebih banyak mengalokasikan sumber pendapatannya untuk belanja pegawai. Seharusnya Pemda mampu mengalokasikan pendapatannya untuk alokasi belanja modal guna percepatan pembangunan dan meraih kesejahteraan daerah.

Hal ini sejalan dengan kesimpulan, bahwa BM tidak dipengaruhi oleh rasio efektivitas PAD (Andriyani, Mukhzarudfa, \& Diah PA (2020) dan Arif \& Arza (2018)).

Namun sejalan dengan rasio efektivitas PAD berpengaruh negatif tidak signifikan pada BM (Indiyanti \& Rahyuda, 2018). Juga sesuai dengan kesimpulan, rasio efektivitas PAD berpengaruh positif tidak signifikan pada (Martini \& Dwirandra, 2015).

4. EKD pada BM

Dapat disimpulkan bahwa Efisiensi KD (X4) berpengaruh terhadap Belanja Modal (Y) sehingga H4 diterima. Hal ini menunjukkan, alokasi belanja modal makin rendah apabila rasio efisiensi semakin tinggi. Suatu program pembangunan disebut efisien jika telah mendapatkan hasil baik dengan input (biaya) rendah/minimal.

Desentralisasi fiskal mengharuskan Pemda mampu mengelola keuangannya secara efisien serta efektif. Pemda hendaknya mampu mencegah pemborosan belanjanya dan bisa lebih efisien. Pemda biasanya terlalu banyak alokasi untuk belanja pegawai yang kurang membawa manfaat untuk kepentingan publik. Seharusnya belanja daerah diprioritaskan untuk belanja modal untuk pembangunan daerah yang bisa berakibat pada peningkatan pendapatan daerah dan mampu menarik minat investor.

Kesimpulan penelitian ini sejalan dengan hasil riset, bahwa BM dipengaruhi oleh rasio (Andriyani, Mukhzarudfa, \& Diah PA, 2020). Sependapat dengan kesimpulan, EKD berpengaruh positif signifikan pada alokasi BM (Arif \& Arza, 2018). Namun bertolak belakang dengan kesimpulan, EKD berpengaruh negatif tidak signifikan pada alokasi BM. (Indiyanti \& Rahyuda, 2018).

\section{IV.KESIMPULAN}

Kesimpulan dari studi ini adalah:

1. Belanja Modal dipengaruhi oleh Kemandirian Keuangan Daerah.

2. Desentralisasi Fiskal berpengaruh pada BM.

3. BM tidak dipengaruhi oleh Efektivitas PAD.

4. Efisiensi KD berpengaruh pada BM.

5. Secara simultan Kemandirian KD, Desentralisasi Fiskal, Efektivitas PAD, dan Efisiensi KD berpengaruh pada BM.

6. Diperoleh nilai adjusted $R^{2}$ sebesar 0.408 , artinya pengaruh variabel KKD, DF, Efisiensi PAD dan Efektifitas KD terhadap BM sebanyak $41 \%$, saldonya $59 \%$ berasal dari variabel lain di luar penelitian ini.

Hasil pengujian serta pembahasan penelitian, maka dihasilkan saran:

1. Pemda harus bisa menggali potensi daerahnya dengan baik dalam rangka peningkatan PAD untuk meminimalkan ketergantungan pada dana transfer dari pemerintah pusat.

2. PAD yang diperoleh hendaknya bisa dikelola secara efektif dan efisien serta mampu mengalokasikannya untuk belanja modal yang berdampak pada kesejahteraan masyarakat.

3. Pemda hendaknya mengalokasikan belanja modal yang berdampak positif bagi peningkatan PAD.

4. Saran untuk penelitian selanjutnya, supaya meneliti kinerja keuangan daerah ditinjau dari sisi pertumbuhan ekonomi, pemerataan ekonomi dan sebaran jumlah penduduk.

\section{DAFTAR PUSTAKA}

Andriyani, N., Mukhzarudfa, \& Diah PA, E. (2020). Pengaruh Kinerja Keuangan Pemerintah Daerah Terhadap Belanja Modal (Studi Di Kabupaten/Kota Provinsi Jambi Tahun 2014 - 2018). Jurnal Akuntansi \& Keuangan UNJA (JAKU), 5(2), 132-144. doi:https://doi.org/10.22437/jaku.v5i2.10263

Arif, M., \& Arza, F. I. (2018). Pengaruh Kinerja Keuangan Terhadap Alokasi Belanja Modal Pemerintah Daerah Di Kabupaten Dan Kota Provinsi Sumatera Barat Tahun 2013 - 2017. Jurnal Riset Manajemen dan Akuntansi, 9(2), 21-36. doi:https://doi.org/10.36600/rma.v9i2.66

Ghozali, I. (2011). Aplikasi Analisis Multivariate Dengan Program SPSS. Semarang: Badan Penerbit Universitas Diponegoro.

Indiyanti, N. M., \& Rahyuda, H. (2018). Pengaruh Kinerja Keuangan Daerah Terhadap Alokasi Belanja Modal Di Provinsi Bali. E-Jurnal Manajemen Universitas Udayana, 7(9), 4713-4746. doi:https://doi.org/10.24843/EJMUNUD.2018.v07.i09.p04

Kajian Belanja Publik Indonesia. (2020, Juni 22). Kajian Belanja Publik Indonesia: Untuk Hasil Yang Lebih Baik. Retrieved from The World Bank: https://thedocs.worldbank.org/en/doc/115401588597386311-0070022020/original/IDPER2020Bahasa.pdf

Martini, K., \& Dwirandra, A. (2015). Pengaruh Kinerja Keuangan Daerah Pada Alokasi Belanja Modal Di Provinsi Bali. E-Jurnal Akuntansi Universitas Udayana, 10(2), 426-443. Retrieved from https://ojs.unud.ac.id/index.php/Akuntansi/article/view/10154/8478

Novita, I., \& Nurhasanah, N. (2020). Pengaruh Kinerja Keuangan Daerah Terhadap Belanja Modal (Studi Pada Pemerintah Daerah Kabupaten/Kota Se-Jawa Barat Periode Tahun Anggaran 2012-2017). Jurnal Buana Ilmu, 4(2), 64-77. doi:https://doi.org/10.36805/bi.v4i2.1050

Sugiyono. (2015). Statistik Nonparametris Untuk Penelitian. Bandung: CV. Alfabeta. 